\title{
Antimicrobial Activity of Trigonella foenum-graecum L. (Fenugreek)
}

\author{
Sharma V, Singh P and Rani A \\ Department of Microbiology, Kanya Gurukul Campus, Gurukul Kangri Vishwavidyalaya, Haridwar, India
}

Corresponding author: Sharma V, Department of Microbiology, Kanya Gurukul Campus, Gurukul Kangri Vishwavidyalaya, Haridwar, India, Tel: +91 1334-252290; E-mail: vanisharma1988@gmail.com

Received Date: October 28, 2016; Accepted Date: February 01, 2016; Published Date: February 07, 2017

Copyright: @ 2017 Sharma V, et al. This is an open-access article distributed under the terms of the Creative Commons Attribution License, which permits unrestricted use, distribution, and reproduction in any medium, provided the original author and source are credited.

Citation: Sharma V, Singh P, Rani A. Antimicrobial activity of Trigonella foenum-graecum L. (Fenugreek). Eur Exp Biol. 2016, 7:1

\section{Abstract}

Traditional uses of plants have led to investigating their bioactive compounds which had resulted in the detection of a significant number of therapeutics properties. Trigonella foenum-graecum L. is believed to be native to the Mediterranean region or Asia; it is one of the most ancient medicinal herbs. Fenugreek contains different alkaloids, flavonoids and saponins. In present studies the antimicrobial activity of Fenugreek leaves, seeds and stem extract (Methanol, Acetone and aqueous extract) against $E$. coli and Staphylococcus were determined by the well diffusion method. The maximum zone of inhibition was given by methanol i.e. $20 \mathrm{~mm}$ and $19 \mathrm{~mm}$ against $E$. coli and Staphylococcus respectively, followed by Acetone extract which give the equal zone of inhibition for both organism i.e. $16 \mathrm{~mm}$ while the aqueous extract shows nill zone of inhibition. Thus from bacteriological point of view Fenugreek leaves and stem appears to play a great role in clinical as well as antibacterial agents.

\section{Keywords: Fenugreek; Antibacterial; E. coli;}

Staphylococcus; Extract

\section{Introduction}

The nature had been a source of medicinal plants for thousands of years since the beginning of man, over the past 20 years; interest in medical plants has grown enormously from the use of herbal products as natural cosmetics and self-medication by the general public for their biological effects. According to the WHO more than $80 \%$ of the world's population relies on plant based herbal medicines for their primary health care needs [1].

Presently there has been an amplified interest worldwide to identify antioxidants compounds which are pharmacologically effective or have low or no side effects for use in preventive medicines and food industries [2]. Herbs and spices been extensively used as food additives for natural antioxidants. Trigonella feonum-graecum L. commonly known as Fenugreek, belongs to the family of Fabaceae. It is the most promising medicinal herb known from ancient time.
Its seeds and green leaves are used in food as well as in medicinal application it provides natural food fiber and other nutrient required in human body [3]. This also helps in nitrogen fixation and soil enrichment [4].

Fenugreek leaves has been found to have ascorbic acid of $220.97 \mathrm{mg} / 100 \mathrm{~g}$ leaves and $\beta$ - carotene of $19 \mathrm{mg} / 100 \mathrm{ml}$ of leaves. It also contains fiber and high amount of calcium, zinc and iron. Seeds of fenugreek have maple flavor and bitter taste but by the process of roasting, their bitterness can be reduced and flavor can be enhanced. Seeds contain volatile oil and fixed oil in small quantities [5]. These are rich source of soluble dietary fibers contain [6]. Fenugreek contains saponins, hemicelluloses mucilage, tannins and pectin and these compounds help to decrease the level of low density lipoprotein cholesterol (LDL) in blood by inhibiting bile salts re- absorption in the colon. Fenugreek seeds are rich in proteins such as globulin, histidine, albumin and lecithin [7].

Fenugreek is a promising protective medicinal herb in cancer patients under chemotherapeutic intervention because fenugreek extract shows a protective effect by modifying the cyclophosphamide induced apoptosis and free radical mediated lipid peroxidation in the urinary bladder of mice [8].

Diosgenin $\left(\mathrm{C}_{27} \mathrm{H}_{42} \mathrm{O}_{43}\right)$ is a crystalline steroid saponins found in fenugreek and used as a sarting material for the synthesis of steroid hormones such as cartison and progesterone, it has been found to be potentially in treatment of cancer [9]. Fenugreek seeds have hypoglyaemic and hypocholesterolemic effect it improves peripheral glucose utilization, contributing to improvement in glucose tolerance and exerts hypoglycemic effect by acting at the insulin receptor level as well as at the gastrointestinal level [10].

Fenugreek contains phenolic and flavonoids compounds which help to enhance its antioxidants capacity [11]. It also have an ability to lower the hepatic lipids in body because of its potential to modify the activities of several enzymes such as enzymes related to glucose and lipid metabolism [12]. Based on several medicinal past reported scientific findings Fenugreek can be various health benefits can be drawn from this natural herb but in some extreme cases like patients suffering from chronic asthma, etc., it should avoided or its consumption should be minimized. 


\section{Materials and Methods}

\section{Collection of sample}

For the isolation of bacteria spoiled cabbage and fresh plants and for antimicrobial activity seeds of Trigonella foenumgraecum were collected from the local market of Haridwar, India.

\section{Isolation and identification of bacteria}

Desired bacteria were isolated from spoiled cabbage by serial dilution method. Selective media such as Mac Conkey, EMB and Mannitol salt agar media were used for the isolation of $E$. coli and Staphylococcus. Identification was carried out on the bases of morphological and biochemical characteristic through gram staining, catalase test, indole production test, methyl red test, voges- proskauer test, starch hydrolysis, sugar fermentation.

\section{Determination of bacterial growth}

The bacterial were inoculated in the broth and incubated in the shaking incubator at $120 \mathrm{rpm}$ and then determine the optical density of nutrient broth at $640 \mathrm{~nm}$ after every 2 hrs [13].

\section{Preparation of extract of fenugreek plant material}

The aqueous and methanol/acetone extraction are prepared of fenugreek plant material for which, weighed 15 gm of leaves, seeds and stems powdered, add $250 \mathrm{ml}$ of sterile distilled water to it, kept the mixture for 7 days and filtered it with muslin cloth, filtrate was allowed for hot extraction process on water bath at $40^{\circ} \mathrm{C}$.

\section{Antimicrobial activity of fenugreek plants}

The antimicrobial activity of fenugreek plants was determined against the E. coli and Staphylococcus by the well diffusion method. Well diffusion method was measured the inhibition zone to know the antimicrobial activity of fenugreek.

\section{Results and Discussion}

\section{Enumeration of microorganism}

Total bacterial colonies were enumerated from the vegetable sample was calculated as CFU on Mac Conkey as well as MSA.

Table $1 \mathrm{CFU} / \mathrm{ml}$ (on Mac conkey).

\begin{tabular}{|l|l|l|}
\hline S.no & Dilution & CFU \pm SE \\
\hline 1. & $10^{-3}$ & $15.67 \pm 0.33$ \\
\hline 2. & $10^{-4}$ & $9.67 \pm 0.33$ \\
\hline 3. & $10^{-5}$ & $5 \pm 0.58$ \\
\hline 4. & $10^{-6}$ & $0.67 \pm 0.66$ \\
\hline
\end{tabular}

Maximum number of bacteria found in $10^{-3}$ on Mac Conkey agar and MSA that is $15.67 \pm 0.33$ and $17 \pm 0.58$ respectively
(Tables 1 and 2). These isolates was identified on the bases of Organisms are characterized on morphological and biochemical characterization (Table 3).

Table $2 \mathrm{CFU} / \mathrm{ml}$ on MSA plates.

\begin{tabular}{|l|l|l|}
\hline S.no & Dilution & CFU \pm SE \\
\hline 1. & $10^{-3}$ & $17 \pm 0.58$ \\
\hline 2. & $10^{-4}$ & $13 \pm 1.16$ \\
\hline 3. & $10^{-5}$ & $8 \pm 0.58$ \\
\hline 4. & $10^{-6}$ & $5 \pm 0.58$ \\
\hline
\end{tabular}

Table 3 Morphological characterization and biochemical characterization.

\begin{tabular}{|c|l|l|l|}
\hline $\begin{array}{c}\text { S } \\
\text { no. }\end{array}$ & Characteristics & E. coli & Staphylococcus \\
\hline 1 & Colour & $\begin{array}{l}\text { Pinkish, metallic } \\
\text { sheen colony }\end{array}$ & $\begin{array}{l}\text { Yellow halo zone } \\
\text { around colonies }\end{array}$ \\
\hline 2 & Cell shape & bacilli & Cocci \\
\hline 3 & Cell arrangement & single & Irregular cluster \\
\hline 4 & Gram's reaction & -ve & + ve \\
\hline 5 & Catalase test & $+v e$ & $+v e$ \\
\hline 6 & Fermentation & Acid+gas & Acid \\
\hline 7 & Starch hydrolys-is & $-v e$ & $-v e$ \\
\hline 8 & Indole & $+v e$ & $-v e$ \\
\hline 9 & Citrate utilize-tion & $-v e$ & -ve \\
\hline 10 & MR & $+v e$ & $+v e$ \\
\hline 11 & VP & $-v e$ & $+v e$ \\
\hline
\end{tabular}

Table 4 Showing OD of bacterial isolate at $540 \mathrm{~nm}$.

\begin{tabular}{|l|l|l|l|}
\hline S no. & Time (hrs) & \multicolumn{2}{|l|}{ Isolates } \\
\hline & & E. coli & Staphylococcus \\
\hline 1 & 0 & 0.016 & 0.007 \\
\hline 2 & 2 & 0.020 & 0.036 \\
\hline 3 & 4 & 0.076 & 0.124 \\
\hline 4 & 6 & 0.120 & 0.240 \\
\hline 5 & 8 & 0.140 & 0.240 \\
\hline 6 & 10 & 0.155 & 0.200 \\
\hline 7 & 12 & 0.152 & 0.184 \\
\hline 8 & 14 & 0.135 & 0.180 \\
\hline
\end{tabular}

After Gram staining and biochemical configuration test the bacteria as Gram negative bacilli (E. coli) and Gram positive cocci in bunches (Staphylococcus) which was isolated from spoiled cabbage. 


\section{Growth curve}

The growth pattern of the isolates was observed by using nutrient broth after every 2 hrs of interval, the following growth pattern was found (Table 4 and Figure 1).

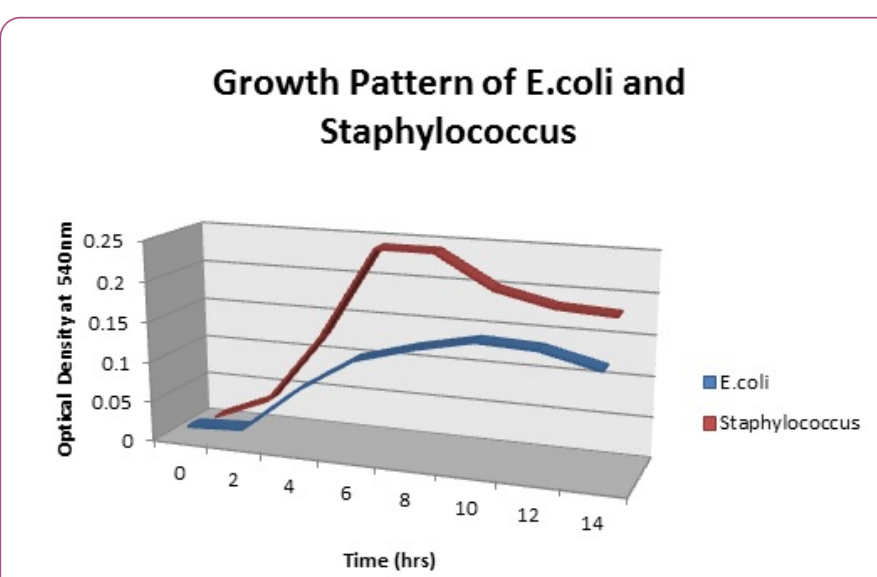

Figure 1 Growth curve of E. coli and Staphylococcus.

\section{Antimicrobial activity of multidrug}

During the study of antibacterial activity of different antibiotics on Staphylococcus out of 12 antibiotics ciprofloxacin and Linezolid give maximum zone of inhibition and in the case of E. coli, Amikacin give maximum zone of inhibition (Tables 5 and 6).

Table 5 Antibiotics sensitivity against Staphylococcus spp.

\begin{tabular}{|l|l|l|l|}
\hline S.no & Antibiotics & code & zone of inhibition $(\mathbf{m m}) \mathbf{R} / \mathbf{S}$ \\
\hline 1. & Ciprofloxacin & CP & $21 S$ \\
\hline 2. & Cephalexin & PR & $16 S$ \\
\hline 3. & Linezolid & LZ & $21 S$ \\
\hline 4. & Levofloxacin & QB & $18 S$ \\
\hline 5. & Roxythromycin & AT & $16 S$ \\
\hline 6. & Lincomycin & LM & $15 S$ \\
\hline 7. & Tetracycline & TE & $15 S$ \\
\hline 8. & Co Trimaxazole & BA & $14 S$ \\
\hline 9. & Ampicillin & AS & $10 R$ \\
\hline 10. & Cloxacillin & CX & $12 S$ \\
\hline 11. & Gentamicin & GM & $16 S$ \\
\hline 12. & Cefotaxime & CF & $9 S$ \\
\hline
\end{tabular}

\section{Antibacterial activity of Trigonella extract}

The result of antibacterial activity of Acetone, Methanol and Aqueous extract of Trigonella's leaves, stem and seeds by agar well diffusion method. Maximum inhibition was observed in methanol extract of leaves shown in Table 7 which is more than the result observed by Premananth et al. in 2011 [14].

Table 6 Antibiotics sensitivity against $E$. coli.

\begin{tabular}{|c|c|c|c|}
\hline S.no & Antibiotics & Code & Zone of inhibition $(\mathrm{mm}) \mathrm{R} / \mathrm{S}$ \\
\hline 1. & Amikacin & AK & $15 S$ \\
\hline 2. & Cefitaxime & $\mathrm{CF}$ & $14 S$ \\
\hline 3. & Gatifloxacin & GF & $14 S$ \\
\hline 4. & Gentamicin & GM & $13 \mathrm{~S}$ \\
\hline 5. & Levofloxacin & QB & $13 \mathrm{~S}$ \\
\hline 6. & Sparfloxacin & SF & $13 \mathrm{~S}$ \\
\hline 7. & Ceftriaxone & $\mathrm{CF}$ & $12 S$ \\
\hline 8. & Tobramycin & TB & $12 S$ \\
\hline 9. & Amphicillin & AS & $11 R$ \\
\hline 10. & Cefadroxil & $\mathrm{CD}$ & $8 \mathrm{R}$ \\
\hline 11. & Olfloxacin & OF & $7 \mathrm{R}$ \\
\hline 12. & Ciprofloxacin & $\mathrm{RC}$ & $5 R$ \\
\hline 13. & Cefixime & $c x$ & $\mathrm{OR}$ \\
\hline 14. & Cefazolin & $\mathrm{CZ}$ & $\mathrm{OR}$ \\
\hline 15. & Norfloxaicn & $\mathrm{NF}$ & $\mathrm{OR}$ \\
\hline
\end{tabular}

Table 7 Antibacterial activity of aqueous extract of fenugreek at $100 \mu \mathrm{l}$.

\begin{tabular}{|c|c|c|c|}
\hline S.no & Plant's Part & \multicolumn{2}{|c|}{ Zone of inhibition $(\mathrm{mm})$} \\
\hline \multicolumn{2}{|c|}{ Aqueous extract } & E. coli & Staphylococcus \\
\hline 1 & Leaves & 4 & 2 \\
\hline 2 & Seeds & 5 & 5 \\
\hline 3 & Stem & 2 & - \\
\hline \multicolumn{2}{|c|}{ Methanol extract } & E. coli & Staphylococcus \\
\hline 1 & Leaves & 20 & 19 \\
\hline 2 & Seeds & - & - \\
\hline 3 & Stem & 13 & 11 \\
\hline \multicolumn{2}{|c|}{ Acetone extract } & E. coli & Staphylococcus \\
\hline 1 & Leaves & 16 & 16 \\
\hline 2 & Seeds & - & - \\
\hline 3 & Stem & 17 & 17 \\
\hline
\end{tabular}

\section{Conclusion}

The present study carried out to determine the antibacterial activity of Fenugreek's leaves, seeds and stem in aqueous, methanol and acetone extract against $E$. coli and Staphylococcus isolated from to be spoiled cabbage which is mostly available at very low cost and widely used by the local street food corners. In further study Methanol extract exhibit the highest zone of 
inhibition as compared to the aqueous extract. In comparison of all the extracts the leaves extracts was found to be maximum as compare to the extracts of seeds and stems. The results were obtained during this experiment were highly effective and comparable with the commercial antibiotic at $100 \mu \mathrm{l}$ concentration of Fenugreek extract. We conclude that out of three solvent extract (Methanol, Acetone and aqueous) the order of antibacterial activities of solvent extract of Fenugreek is Methanol>Acetone>Aqueous.

\section{Reference}

1. Shanmugasundaram S (2005) Complementary and Alternative therapies in palliative and care; A transition from modern medicine to traditional medicine. Ind J Cancer Pain Symp Palliation 1: 25-29.

2. Sati SC, Sati N, Rawat U, Sati OP (2010) Medicinal plants as a source of antioxidants. Res J Phytochem 4: 213-224.

3. Thomas JE, Bandara M, Lee EL, Driedge D, Acharya S (2011) Biochemical monitoring in fenugreek to develop functional food and medicinal plants variants. $\mathrm{N}$ Biotechnol 28 : 110-117.

4. Montgomery J (2009) The potential of fenugreek (Trigonella foenum- graecum) as a forage for dairy herbs in central Alberta. University of Alberta USA 4-15.

5. Sowmya P, Rajyalakshmi P (1999) Hypocholesterolemic effect of germinated fenugreek seeds in human subjects. Plants foods Hum Nutr 53: 359-365.

6. Sharma RD, Raghuram TC (1990) Hypoglycaemic effect of fenugreek seeds in non-insulin dependent diabetic subjects. Nutri Res 10: 731-739.
7. Mathur P, Choudhary M (2009) Consumption pattern of fenugreek seeds in Rajasthani families. J Hum Ecol 25: 9-12.

8. Bhatia K, Kaur M, Atif F, Ali M, Rehman H, et al. (2006) Aqueous extract of Trigonella ameliorates additive urotoxicity of buthionine sulfoximine and cyclophosphamide in mice. Food Chem Toxicol 44: 17441750.

9. Aggrawal BB, Shishodia S (2006) Molecular targets of dietary agents for prevention and therapy of cancer. Biochem Pharmacol 71: 1397- 1421.

10. Singh V, Garg AN (2006) Availability of essential trace elements in Indian cereals, vegetables and spices using INAA and the contribution of spices to daily dietary intake. Food Chem 94: 81-89.

11. Dixit P, Ghaskadbi S, Mohan H, Devasagayam TP (2005) Antioxidants properties of germinated fenugreek seeds. Phytother Res 19: 977- 983.

12. Madar Z, Shomer IJ (1990) Polysaccharide composition of a gel fraction derived from fenugreek and its effect on starch digestion and bile acid absorption in rats. J Agric Food Chem 38: 1435- 1539.

13. Singh P, Rani A, Chaudhary N (2015) Isolation and characterization of protease producing Bacillus $\mathrm{sp}$ from soil. Int J Pharm Sci Res 6: 633-639.

14. Premanath R, Sudisha J, Lakshmi Devi N, Aradhya SM (2011) Antibacterial and antioxidant activity of Fenugreek (Trigonella foenum graecum L.) leaves. Res J Med Plants 5: 695-705. 